\title{
Self-perception as an Inclusive Victim of Oppression, Intergroup Emotions and Support for Resistance to the Victimization of Disadvantaged Outgroups
}

\author{
Gustave Adolphe Messanga, Kelvine Aristote Youmbi, Hermann Kevin Ekango Nzekaih \\ Department of Philosophy, Psychology and Sociology, University of Dschang, Dschang, Cameroon \\ Email address: \\ messangaadolphe@gmail.com (G. A. Messanga) \\ To cite this article: \\ Gustave Adolphe Messanga, Kelvine Aristote Youmbi, Hermann Kevin Ekango Nzekaih. Self-perception as an Inclusive Victim of \\ Oppression, Intergroup Emotions and Support for Resistance to the Victimization of Disadvantaged Outgroups. Psychology and Behavioral \\ Sciences. Vol. 10, No. 5, 2021, pp. 165-177. doi: 10.11648/j.pbs.20211005.12
}

Received: August 31,2021; Accepted: September 23, 2021; Published: September 29, 2021

\begin{abstract}
The literature on collective victimization indicates that individuals who experience victimization very often engage in resistance behaviors in order to change their current or past situation. This resistance is likely to generate conflicts with the oppressors. Numerous works are interested in this aspect by emphasizing the role of the main actors involved (aggressor/victim); in turn neglecting actors who are not directly involved in the conflict such as witnesses; hence the interest of this research for this poorly documented aspect of the psychosocial literature on resistance against oppression. Specifically, it is interested in the connection between self-perception as an inclusive victim, the resulting emotions and resistance to outgroups' oppression. The hypothesis of the study proposes that intergroup emotions have a moderating effect on the link between self-perception as an inclusive victim of oppression and support for the resistance to the victimization of disadvantaged outgroups. To test it, 658 Francophones of both sexes were selected to participate in a psychosocial survey carried out in the city of Dschang (Cameroon). Their average age is 25 years. The scales that were self-administered to them are as follows: self-perception as an inclusive victim $(\alpha=.69)$, resistance to victimization $(\alpha=.90)$, nostalgia for others $(\alpha=.92)$, collective guilt $(\alpha=.74)$, empathy for others $(\alpha=.87)$, collective shame $(\alpha=.74)$ and collective grievances $(\alpha=.88)$. The data collected provide empirical support for the hypothesis of the study. It is concluded that intergroup emotions have a moderating effect on the link between self-perception as an inclusive victim of oppression and support for the resistance to the victimization of a disadvantaged outgroup.
\end{abstract}

Keywords: Self-perception as an Inclusive Victim, Resistance to Oppression, Intergroup Emotions, Witnesses, Collective Victimization

\section{Introduction}

Researches on collective victimization generally focuses on the actors (aggressors and victims); neglecting the role of third parties or witnesses [49]. However, they are as important in the resolution of conflicts as the main protagonists [63]. If, moreover, these witnesses perceive themselves as inclusive victims of oppression, their propensity to take part in the conflict or their involvement may contribute to its perpetuation or its end [64]. In this vein, the specialized literature reveals that while the perpetuation of conflicts is often observed in cases where witnesses are passive, their stopping, on the other hand, is generally the consequence of their concrete actions [64]. The choice of passivity or concrete actions is determined by the affects that individuals may feel [16]. This means that the inaction of certain groups or on the contrary their active engagement in a conflict would find an explanation in intergroup emotions. The present study is within this perspective of analysis.

\subsection{Oppression and Collective Victimization}

Intergroup oppression refers to various forms of violence, including conflicts between nations or groups, terrorism, genocide, human rights violations or various deprivations of which a group may be the victim [66]. It is approached through the prism of attitudes, emotions and behaviors 
resulting from the harm inflicted on a group by one or more other groups [75]. There are two forms: structural and direct [23]. The first is linked to inequalities or discrimination in health, housing, education and employment, with a potential impact on the quality of life of individuals [14]. In other words, it is a type of violence that is expressed through policies, laws, or any other unfavorable system. The second refers to the harm that results, among others, from phenomena such as colonization, slavery, ethnic conflicts, terrorism, crimes, wars and genocides. One cannot analyze intergroup oppression without taking collective victimization into account, since the latter is a consequence of collective violence. It refers to the belief that ingroup members were intentionally and baselessly injured by another group [31]. This belief can generate a feeling of collective victimization and, as a result, lead to various reactions from the members of the groups that are its targets, including in particular violent or non-violent behavior of resistance to oppression.

\subsection{Resistance to Oppression}

Due to the fact that oppression seems to be omnipresent in today's world, group resistance to this phenomenon can be seen as a daily struggle maintained by both individual and collective initiatives. However, the literature on conflicting intergroup relations tends to focus on the inertia or powerlessness of groups in the face of collective oppression [49]; in turn neglecting resistance to this oppression [26, 80]. If despite its daily presence, resistance to oppression remains less visible than victimization, it is undoubtedly because it involves opposition action [26], and therefore probably much more violence in an already unfavorable situation. Indeed, it can be defined as any action which aim is not only to oppose the violence or oppression of one or more groups, but also to thwart its objectives [69]. Clearly, resistance is a weapon of defense used by victimized groups to respond to the oppression of which they are victims. It is closely linked to collective victimization and power. In this vein, collective victimization is seen as a consequence of violence, the unfair implications of which on basic human needs and life in general are inevitable [80]. Power, on the other hand, refers to the ability to meet these different needs [54]. Thus, collective victimization and power are two ingredients that fuel the tendency to resist [47], insofar as resistance to oppression or the struggle to escape from it are motivated by the idea that it is in itself a form of conquest or rehabilitation of power [56]. In this logic, one can suggest that the instrumental goal of the acts of resistance is a desire for justice and a modification of the status quo to the advantage of the victimized group.

In the psychosocial literature, the operationalization of resistance to oppression is grafted onto that of collective action, considered as a form of resistance [9]. Intensity is one of the characteristics by which it can be defined; hence the distinction between violent and non-violent resistance [80]. Both are organized around distinct strategies for action. Due to the fact that the former includes the destruction of public property and acts of vandalism, it approaches or even merges with non-normative protest. The second, on the other hand, includes peaceful demonstrations with permission, signing petitions or participating in acts of civil disobedience. Confused with normative protest, it implies a controlled and responsible resistance. Resorting to any of these forms of resistance is not necessarily deliberate; sometimes it's just a default choice. This is the case with resistance during the Holocaust when groups opted for nonviolent strategies because of difficulties in gaining possession of weapons or means equivalent to Nazi oppression [19, 20]. In other circumstances, the choice is determined by the perceived effectiveness of strategies, the actions of the oppressor, and other external conditions [5, 26, 58]. For example, during the Second Intifada, support for violent resistance strategies was high, regardless of its perceived effectiveness, due to the fact that nonviolent resistance was not perceived to be effective [58]. In other situations, the lethal risk, the probability of a favorable outcome, but also the relationship or degree of attachment to the group are taken into account to determine the resistance strategies that it will adopt [34].

Identification with ingroup is essential in the analysis of collective victimization. Indeed, in order to understand the related attitudes, one must take into account the identity content, the strength of the identity and common identities [75]. They refer, to a certain extent, to social identity. The content of identity goes far beyond mere identification as a member of a group, as it shapes people's perceptions and reactions to collective victimization [50]. In other words, they are psychological implications such that they modulate the attitudes of individuals towards victimization. Strength of identity, on the other hand, refers to the degree to which individuals identify with either an ingroup or outgroup. On the other hand, it predicts a higher tendency towards competitive victimization and conversely, less positive attitudes towards outgroups. In terms of common identity, the literature shows that identifying groups as members of a common category improves relationships in the context of victimization and thereby predicts positive intergroup attitudes [50]. This factor can generate a feeling of inclusive/exclusive victimization. This research places particular emphasis on these two forms of victimization.

\subsection{Self-perception as an Inclusive Victim and Resistance to Oppression}

Resistance to oppression or victimization is a consequence of collective victimization which can be expressed in many forms. Individuals' way of thinking and beliefs may more or less cause them to focus on how they have suffered, distinct from other groups: this is the consciousness of the exclusive victim [77]. This concept relates to the fact that in a situation of collective victimization, the members of the ingroup see themselves as the only ones to be taken into account. In this framework precisely, the beliefs of the victim are all centered on the ingroup and differ according to their frame of reference. For example, two groups engaged in a conflict may claim the status of victim, regardless of the suffering of the other. 
In line with works on the feeling of victimization, researchers' attention is also focused on the perceived similarity between the suffering of ingroup and that of outgroups. For individuals or groups, it is about perceiving their suffering also in others: it is the consciousness of the inclusive victim [77]. It implies that in a specific conflict, individuals perceive similarities related to experiences of suffering with outgroups who are not necessarily adversaries in the conflict. Inclusive victim awareness can be generated through intergroup contact or listening to the others' history or life experiences [4]. By way of illustration, one can cite the circles of parents bereaved by the Arab-Jewish conflict in the Gaza Strip (family of peace). This circle brings together Palestinian and Israeli parents who campaign for peace between the two groups on the basis of the mourning they share [37]. In such a conflict, the consciousness of the inclusive victim is psychologically stronger when the groups perceive similarities in terms of the costs of the conflict (global awareness of the inclusive victim; [75]). In other words, the fact that individuals have similar experiences in a conflict is an element that reinforces the feeling of being an inclusive victim. This means that above all, conflict situations pose the crucial problem of categorization.

In intergroup conflicts, those involved tend to make comparisons on the basis of similarities and differences in experienced oppression. These comparisons have an impact on the degree of inclusion of groups as victims. Particularly in some situations, it is possible that after a conflict, not only do groups come to the conclusion that they have had similar experiences, but also come to recognize the differences in certain aspects of the conflict, such as its nature or the extent of victimization [50]. In this vein, the theoretical literature on supra-ordered identity notes that despite the fact that individuals or groups identify themselves subjectively, in certain contexts, as members of the same supra-category, they may still prefer the identity of their sub-category of membership [16]. This is the primacy of the need for distinctiveness [11].

Common or supra-ordered identities are created following a psychological process of re-categorization. This process aims to put ingroup and outgroup members together into a single category with which they will identify [53]. In this wake precisely, when individuals share similar experiences of suffering or when they see themselves as common victims of conflict, they may recategorize themselves as members of the supra-category [78]. In other words, when the suffering experienced of a group is salient, outgroups that have suffered the same harms identify the victims as belonging to a common ingroup (inclusive victim consciousness). This process of identification with a common category of victims has positive consequences on intergroup attitudes or behaviors.

The perception of groups as inclusive victims of conflict can generate behavioral and attitudinal changes among them. In fact, perceived similarities and identification of groups as common victims have a positive effect on prosocial attitudes towards outgroups. Thus, positive attitudes towards victim groups are predicted by the feeling of being also a victim of conflict [75]. This hypothesis is supported by a study conducted among American citizens of Jewish origin. It reveals that when the Holocaust was described to participants in an inclusive manner, while taking into account the distinct plight of the groups, their willingness to support the victims of Darfur increased [76]. Similarly, in the Judeo-Israeli context, the similarities between Holocaust and other genocides motivated the aid given to certain victim groups [35]. Research also reports that individuals who have suffered harm in life are more likely to behave altruistically towards those in need [78]. What are the factors likely to explain these observations reported in the literature?

\subsection{Self-perception as Inclusive Victim of Oppression, Intergroup Emotions and Support for Resistance Against Victimization of Disadvantaged Outgroups}

The existing literature reveals that the link between emotions and protest is based on the feeling of relative deprivation. This feeling arises from the fact that after comparisons with individuals or groups that are similar to them, people perceive themselves as disadvantaged because there is, according to them, a gap between what they should be or have and what they are or have [25]. After experiencing it, they can engage in collective actions of a prosocial nature, in particular because intergroup emotions contribute to the adoption of positive behaviors towards disadvantaged groups. Indeed, studies of protest show that individuals participate to express their grievances in relation to relative deprivation, frustration or perceived injustice [7, 36, 39, 48, 52]. These grievances arise when people feel relatively deprived for themselves, for their group or for others; due to the fact that they are facing life conditions they did not expect [8].

Other affects are involved in the propensity to engage in collective action. These include nostalgia, which leads to the adoption of favorable behaviors towards outgroup. It refers to the feeling that the past of a person, its group, or another person was better compared to the present [13]. It can be experienced for oneself, for others or for a group [61], in a negative or positive aspect. On the negative side, individuals who experience nostalgia may engage in hostile behavior towards outgroup, especially if they have grievances against their members. In its positive aspect, it allows the reduction of prejudices and negative attitudes towards outgroup, insofar as it promotes engagement in lasting, desirable and memorable interactions with others, including in particular the manifestation of prosocial behaviors [81].

Collective guilt and shame are also emotions that mutually motivate individuals to behave positively towards low status groups. Indeed, the literature reveals that they are more linked to situations of violence or oppression [40]. They generate negative emotional states that prompt individuals to take prosocial action towards the ingroup or outgroup involved in the event $[29,71]$. Thus, collective action and positive intergroup behaviors that individuals undertake strongly depend on the nature of the emotion being experienced [72]. In other words, the quality of intergroup relationships is closely related to the nature of the emotion 
experienced. The literature on this subject reveals that there are links between collective guilt and the support of populations for redressing intergroup tensions [28, 38]. For example, a study conducted in the Cameroonian linguistic context reports that the group guilt felt by Francophones motivates them to support the reparation of oppression towards the anglophone linguistic outgroup [45]. In short, guilt and shame are emotions that predispose individuals to adopt positive behaviors vis-à-vis oppressed groups.

If the studies cited above set out to show that intergroup emotions play a role in the behavior of individuals towards groups victimized by ingroup, the fact remains that the literature does not report data on the specific behavior of inclusive victims in this area. Indeed, the research protocols of these studies are in the perspective of exclusive victimization. However, the particularity of inclusive victimization compared to exclusive victimization relates to the fact that the individuals concerned also experience suffering. Because of its painful nature, it makes it difficult to predict emotional reactions and therefore supportive behaviors towards the also victimized outgroup; hence the interest of this research. In this vein, it sets itself the objective of investigating this undocumented aspect of the literature on resistance to victimization, by answering the following research question: what is the effect of intergroup emotions on the relationship between self-perception as an inclusive victim of oppression and support of resistance to the victimization of a disadvantaged outgroup?

\subsection{Hypotheses}

The present study tests the following main hypothesis: intergroup emotions have a moderating effect on the link between self-perception as an inclusive victim of oppression and support for the resistance to the victimization of a disadvantaged outgroup. In detail, it is expected that participants' self-perception as inclusive victims of outgroup oppression will generate: 1) nostalgia for others; 2) empathy for others; 3) collective guilt; 4) collective shame; and 5) collective grievances that will elicit their support for the resistance against outgroup's victimization.

\section{Method}

\subsection{Participants}

The participants are 658 students of both sexes attending various faculties of the University of Dschang (Cameroon). Their average age is 25 years. They were selected using the simple random sampling method. They all belong to the francophone linguistic community; due to the fact that the study aims to measure the emotions felt by members of this community towards to the oppression that the governing system inflicts on the anglophone outgroup.

\subsection{The Intergroup Context of the Study}

The secessionist crisis underway in the anglophone regions of Cameroon sometimes gives them the aspects of a war zone: arrests, ghost towns, indiscriminate killings, deterioration of the living conditions of populations, destruction of certain villages, kidnappings, killings of civilians and soldiers $[51,68]$. In addition to this social and security aspect, there is the psychological trauma of which the populations are victims. Beyond this direct violence, their feeling of victimization is reinforced by structural violence. Indeed, Anglophones consider themselves marginalized by the Cameroonian political system [22]. However, marginalization has a double meaning, due to the fact that it implicitly admits that another group is privileged: the Francophones obviously. Is this indeed the case?

On analysis, some Anglophones complaints lack a solid foundation. For example, it is difficult to prove that their underemployment is due to the manifest will of the governing authorities or that the latter are engaged in a genocidal logic in their attempt to restore security in the anglophone regions of the country plagued by a secessionist crisis. By way of illustration, a study reveals that the threats linked to unemployment, poverty, hunger and health risks are less felt in the two anglophone regions than in the eight francophone regions of Cameroon $(32 \%$ in the North West, $42 \%$ in the South-West, against $57 \%$ in the other regions) [57]. In the same vein, when it comes to discrimination, both Francophones and Anglophones feel the same (68\% of Anglophones complain of being discriminated against, compared to $60 \%$ of Francophones) [57].

The data presented above shed more light on a widespread phenomenon across the country, rather than discriminatory treatment targeted at Anglophones. Despite this, they feel marginalized and oppressed. This can be understood by the fact that the feeling of victimization is often tinged with subjectivity. In this case, it pushes Anglophones or a part of them to behave like victims, in particular by adopting resistance behaviors. In the same vein, it cannot be disputed either that the government authorities, responding to the grievances raised by Anglophones, have taken remedial measures. However, Anglophones in general, and their more radical fringes in particular, see them as a dusting and therefore a subtle way of maintaining structural oppression. If we add to this rejection the multiple uses of the repressive apparatus or the arrests and departures in exile, for Anglophones, at least the most committed, resistance continues; hence the fact that the current crisis has revived the secessionist tendencies of the past [45].

One can question the veracity of the above, not on the difficult living conditions of Anglophones, but on the privileged status they assign to their Francophone compatriots. There are, in fact, reasons to believe that the socioeconomic and political situation of Cameroon is badly experienced by both Anglophones and Francophones. Despite the stability that the governing system knows, young graduates are forced into odds and ends and small trades [63]. At the sociopolitical level, repression is the systematic response to any inclination to challenge power, regardless of the linguistic group to which the protesters belong [46]. As a result, both Francophones and Anglophones often find 
themselves in prison for expressing political opinions or for organizing anti-system protests; and sometimes without trial.

It emerges from the above that in Cameroon, collective victimization is not experienced especially by Anglophones. This perception calls into question the grievances they raise, or at least their formulation. These considerations allow us to suggest that in the context of the current crisis in the regions of the former British Cameroon, it would be less an oppression perpetrated by Francophones against Anglophones, than an oppression of the governing system against citizens (Francophones and Anglophones included), since the members of the two linguistic communities demand more jobs, infrastructures, social security or the right to demonstrate peacefully from the government [57]. Francophones can therefore be seen as inclusive victims of the direct and structural oppression Anglophones are complaining about. However, the two groups differ from each other from the point of view of conflictuality, since the clashes between the national army and the anglophone separatist groups take place mainly in the territory of the former British Cameroon and that the vast majority of the victims of this conflict are people from this geographical area. Thus, Francophones can be considered as direct witnesses of the conflict between the governing system and Anglophones (see [64]). The present study proposes that given this position and the possibility that they perceive themselves as inclusive victims of oppression, they might experience favorable emotions for Anglophones and therefore support them in the face of the oppression that they undergo. It is this idea that is subjected to empirical verification.

\subsection{Material and Procedure}

The present study comprises three (3) main variables and fifteen (15) control variables. Each is assessed using a specific psychometric instrument.

\subsubsection{Measures of the Main Variables of the Study}

The instruments to measure the main variables of this study are as follows: 1) the scale of self-perception as an inclusive victim of oppression $(\alpha=.69$; [79]). It has three (3) right-coded items and makes it possible to evaluate whether Francophones see themselves as inclusive victims of the oppression suffered by Anglophones; 2) The Anglophone Victimization Resistance Support Scale $(\alpha=.90$; [67]). It is designed to gauge the support for resistance towards the oppression of the anglophone minority in Cameroon. It has 6 items distributed equally over two dimensions. The first is non-violent resistance and the second is violent resistance; 3 ) the scales that measure intergroup emotions analyze various emotions including: the nostalgia for others that Francophones might feel for their victimized Anglophones compatriots $(\alpha=.92 ;[15])$; the feeling of empathy $(\alpha=.87$; [15]) which makes it possible to assess empathy for others; collective guilt ( $\alpha=.74$; [45]) to assess the guilt felt by Francophones vis-à-vis their Anglophone compatriots; collective shame to measure the shame felt by Francophones as a result of the treatment inflicted on Anglophones $(\alpha=.74$; [45]); and the measure of grievances against the government
( $\alpha=.88$; [67]) which allows us to determine the grievances that Francophones have against the governing system. For all these scales, participants should mark their degree of agreement or disagreement on each item on a 7 points Likert scale ranging from 1 (strongly disagree) to 7 (strongly agree).

\subsubsection{Measures of Control Variables}

The scales for capturing control variables are as follows: 1) the perceived effectiveness of resistance support scale $(\alpha=.93 ;[6]) ; 2)$ the perceived entitativeness of the supraordered group scale $(\alpha=.67 ;[44]) ; 3)$ the scale of belief in a just world $(\alpha=.84 ;[62]) ; 4)$ the social system justification scale $(\alpha=.86 ;[32]) ; 5)$ the linguistic system justification scale $(\alpha=.82 ;[21]) ; 6)$ the scale of belief in meritocracy $(\alpha=.91 ;[60]) ; 7)$ the social dominance orientation scale of $(\alpha$ $=.80 ;[55]) ; 8)$ the linguistic dominance orientation scale $(\alpha=.70 ;[73])$; 9) the right-wing authoritarianism scale $(\alpha=.80 ;[3]) ; 10)$ the identification with the nation' scale $(\alpha=.85 ;[74]) ; 11)$ the blind patriotism scale $(\alpha=.76 ;[59])$; 12) the constructive patriotism scale $(\alpha=.77$; [59]); 13) the generic conspiracist beliefs scale $(\alpha=.85 ;[12]) ; 14)$ the feeling of solidarity towards outgroup's scale $(\alpha=.73$; [6]); and 15) the moral obligation scale $(\alpha=.80 ;[6])$. For all these psychometric instruments, the task of the participants is to give their opinion for each item on a 7 points Likert scale, ranging from 1 (strongly disagree) to 7 (strongly agree).

\section{Results}

The results of this research are presented in three stages. First, we analyze the data on the main variables, in order to test the hypotheses of the study. Next, we examine the scores of the participants in the control measures relating to personal dispositions. Finally, their scores for the control measures relating to their ideological dispositions are reported.

\subsection{Analysis of Data Related to the Main Variables of the Study}

In this section, we present the descriptive and inferential analyzes of the main variables of the study.

Descriptive and inferential analysis of the main variables of the study.

Table 1. Descriptive statistics of the main variables of the study.

\begin{tabular}{lll}
\hline Measures & M & SD \\
\hline 1. Self-perception as an inclusive victim & 14,02 & 2,568 \\
2. Nostalgia for others & 32,07 & 6,403 \\
3. Empathy for others & 17,16 & 3,990 \\
4. Collective guilt & 7,32 & 3,170 \\
5. Collective shame & 8,49 & 3,558 \\
6. Collective grievances & 9,35 & 3,313 \\
7. Non-violent resistance & 15,26 & 4,126 \\
8. Violent resistance & 11,21 & 4,319 \\
9. Overall resistance to outgroup's victimization & 26,47 & 6,354 \\
\hline
\end{tabular}

The results of Table 1 show that the inclination to see themselves as inclusive victims of the oppression against Anglophones was high among participants $(\mathrm{M}=14,02 ; \mathrm{SD}=$ 
2,56). The same general tendency is observed for the feeling of nostalgia for others $(\mathrm{M}=32,07 ; \mathrm{SD}=6,40)$. Likewise, participants experience empathy $(\mathrm{M}=17,16 ; \mathrm{SD}=3,99)$ and collective guilt $(\mathrm{M}=7,32 ; \mathrm{SD}=3,17)$. The data collected also report a high feeling of collective shame among the participants $(M=8,49 ; \mathrm{SD}=3,55)$. The same is true for collective grievances $(M=9,35 ; \mathrm{SD}=3,31)$. The results also reveals that participants support non-violent resistance to Anglophones oppression $(\mathrm{M}=15,26 ; \mathrm{SD}=4,12)$ more than violent resistance $(\mathrm{M}=11,21 ; \mathrm{SD}=4.31)$. They also indicate that participants agree with the overall resistance to outgroup's victimization ( $\mathrm{M}=26,47 ; \mathrm{SD}=6,35)$.

Table 2. Correlations between the main variables of the study.

\begin{tabular}{|c|c|c|c|c|c|c|c|c|}
\hline Measures & 1 & 2 & 3 & 4 & 5 & 6 & 7 & 8 \\
\hline 1. Self-perception as an inclusive victim & 1 & & & & & & & \\
\hline 2. Nostalgia for others & $-.007(.85)$ & 1 & & & & & & \\
\hline 3. Empathy for others & $.001(.99)$ & $.479^{* *}(.00)$ & 1 & & & & & \\
\hline 4. Collective guilt & $.075(.05)$ & $.062(.11)$ & $.088^{*}(.02)$ & 1 & & & & \\
\hline 5. Collective shame & $.050(.19)$ & $176^{* *}(.00)$ & $.190^{* *}(.00)$ & $.404^{* *}(.00)$ & 1 & & & \\
\hline 6. Collective grievances & $.090^{*}(.02)$ & $.141^{* *}(.00)$ & $.216^{* *}(.00)$ & $.288^{* *}(.00)$ & $.472^{* *}(.00)$ & 1 & & \\
\hline 7. Non-violent resistance & $-.009(.81)$ & $.195^{* *}(.00)$ & $.195^{* *}(.00)$ & $.179^{* *}(.00)$ & $.155^{* *}(.00)$ & $.196^{* *}(.00)$ & 1 & \\
\hline 8. Violent resistance & $.021(.59)$ & $-.058(.13)$ & $-.057(.14)$ & $.223^{* *}(.00)$ & $.181^{* *}(.00)$ & $.233^{* *}(.00)$ & $.132^{* *}(.00)$ & 1 \\
\hline $\begin{array}{l}\text { 9. Overall resistance to outgroup's } \\
\text { victimization }\end{array}$ & $.008(.83)$ & $.087^{*}(.02)$ & $.088^{*}(.02)$ & $.268^{* *}(.00)$ & $.224^{* *}(.00)$ & $.285^{* *}(.00)$ & $.739^{* *}(.00)$ & $.765^{* *}(.00)$ \\
\hline
\end{tabular}

Note: $r(p) *$. The correlation is significant at the 0.05 level (two-tailed). **. The correlation is significant at the 0.01 level (two-tailed).

Table 2 shows that the general trend of the link between self-perception as an inclusive victim of oppression and the feeling of nostalgia for others is negative and not significant $(\mathrm{r}=-.007 ; p>.05)$. On the other hand, its link with the feeling of empathy for others $(\mathrm{r}=.001 ; p>.05)$, the feeling of collective guilt $(\mathrm{r}=.075 ; p=.05)$ and the feeling of collective shame $(\mathrm{r}=.05: p>.05)$ is positive. It is the same with collective grievances $(\mathrm{r}=.90 ; p<.05)$. On the other hand, its link is negative with non-violent resistance to outgroup's victimization $(\mathrm{r}=-.009: p>.05)$, and positive with violent resistance $(\mathrm{r}=.02 ; p>.05)$ and global resistance $(\mathrm{r}=.008$; $p>.05)$. Regarding the links between different emotions and overall resistance to outgroup's victimization, the data collected show a positive and significant link between nostalgia for others and overall resistance $(\mathrm{r}=.087 ; p<.05)$ and a positive and significant link between empathy for others and overall resistance $(\mathrm{r}=.088 ; p<.05)$. The same tendency is observed between the feeling of collective guilt and the overall resistance $(\mathrm{r}=.26 ; p<.01)$, between the feeling of collective shame and the overall resistance $(\mathrm{r}=.22$; $p<.01$ ), and between collective grievances and overall resistance $(\mathrm{r}=.28 ; p<.01)$. These results provide support for the general hypothesis of the study. Regression analyzes also point in this direction.

Table 3. Regression analysis: 1) between self-perception as an inclusive victim of oppression and the main variables of the study; and 2) on the moderating role of intergroup emotions on the overall support of resistance to outgroup's victimization.

\begin{tabular}{|c|c|c|c|c|c|c|}
\hline \multirow{2}{*}{ Model } & \multicolumn{2}{|c|}{ Unstandardized coefficients } & \multirow{2}{*}{$\mathbf{T}$} & \multirow{2}{*}{ Sig. } & \multicolumn{2}{|c|}{$95.0 \%$ confidence interval for $B$} \\
\hline & B & Standard error & & & Lower bound & Upper bound \\
\hline \multicolumn{7}{|c|}{ Indicators of the effect of self-perception as an inclusive victim of oppression on the main variables of the study } \\
\hline 1. Overall resistance to outgroup's victimization & .020 & .097 & .209 & .834 & -.169 & .210 \\
\hline 2. Nostalgia for others & -.018 & .097 & -.181 & .857 & -.209 & .174 \\
\hline 3. Empathy for others & $-9,18$ & .061 & .002 & .999 & -.119 & .119 \\
\hline 4. Collective guilt & .092 & .048 & 1,920 & .055 & -.002 & .187 \\
\hline 5. Collective shame & .070 & .054 & 1,295 & .196 & -.036 & .176 \\
\hline \multicolumn{7}{|l|}{ Indicators of the moderating effect of personality traits } \\
\hline 2. Nostalgia for others & .086 & .039 & 2,233 & .026 & .010 & .162 \\
\hline 3. Empathy for others & .139 & .062 & 2,252 & .025 & .018 & .261 \\
\hline 4. Collective guilt & .537 & .075 & 7,122 & .000 & .389 & .685 \\
\hline 5. Collective shame & .400 & .068 & 5,883 & .000 & .266 & .533 \\
\hline 6. Collective grievances & .547 & .072 & 7,627 & .000 & .406 & .688 \\
\hline
\end{tabular}

Note: Dependent variable: Overall resistance to outgroup's victimization.

Table 3 presents the indicators of the results of the effect of self-perception as an inclusive victim of oppression on the main variables of the study and the moderating role of intergroup emotions on the overall support for resistance to outgroup's victimization. It indicates that self-perception as an inclusive victim of oppression acts positively on resistance to outgroup's victimization $(\beta=.02 ; \mathrm{t}=.20 ; p>.05 ; \mathrm{Ci}[-.16 ; .21])$. In details: 1$)$ self-perception as an inclusive victim of oppression has a negative and insignificant effect on nostalgia for others $(\beta=-.01$; $\mathrm{t}=.20 ; p>.05$; Ci[-.20;.21]) which has a positive and significant effect on the overall resistance to outgroup's victimization $(\beta=.08 ; \mathrm{t}=2.23 ; p<.05 ; \mathrm{Ci}[.10 ; .16])$. This result provides empirical support for hypothesis 1 of the study; 2) selfperception as an inclusive victim of oppression has a negative 
and insignificant effect on empathy for others $(\beta=-9.1 ; \mathrm{t}=.002$; $p>.05$; Ci[. $11 ; .17])$. Likewise, empathy for others has a positive and significant effect on overall resistance to outgroup's victimization $(\beta=.13 ; \mathrm{t}=2.25 ; p>.05 ; \mathrm{Ci}[.01 ; .26])$. This result confirms hypothesis 2 of the study; 3 ) self-perception as an inclusive victim of oppression has a positive effect on collective guilt $(\beta=.09 ; \mathrm{t}=1.9 ; p>.05 ; \mathrm{Ci}[-.002 ; .18])$ which, for its part, has a positive effect on overall resistance to outgroup's victimization $(\beta=.53 ; \mathrm{t}=7,1 ; p<.01 ; \mathrm{Ci}[.38 ; .68])$. This result provides support for Hypothesis 3 of the study; 4) selfperception as an inclusive victim of oppression has a positive effect on collective shame $(\beta=.07 ; \mathrm{t}=1,2 ; p>.05 ; \mathrm{Ci}[-$ $.036 ; .17])$. This positive effect is also observed between collective shame and the overall resistance to outgroup's victimization $(\beta=.40 ; \mathrm{t}=5,8 ; p<.01 ; \mathrm{Ci}[.26 ; .53])$. This result supports hypothesis 4 ; and 5) self-perception of as an inclusive victim of oppression has a positive effect on collective grievances $(\beta=.11 ; \mathrm{t}=2,3 ; p>.05 ; \mathrm{Ci}[.01 ; .21])$. These grievances also have a positive effect on the overall resistance to outgroup victimization $(\beta=.54 ; \mathrm{t}=7,6 ; p<.01 ; \mathrm{Ci}[.40 ; .68])$. This observation supports Hypothesis 5. The analyzes of control variables allow further testing of these hypotheses.

\subsection{Descriptive and Inferential Analyzes of the Control Variables of the Study}

This section presents the analyzes relating to the control variables relating to the personal dispositions and ideological dispositions of the participants.

\subsubsection{Analyzes Relating to Control Variables Specific to Personal Arrangements}

Here, we dwell on the control variables specific to participants' personal dispositions.

Table 4. Descriptive and correlation statistics between the control variables relating to personal dispositions and the overall support for resistance to outgroup's victimization

\begin{tabular}{|c|c|c|c|c|c|c|c|c|c|c|}
\hline Measures & 1 & 2 & 3 & 4 & 5 & 6 & 7 & 8 & $\mathbf{M}$ & SD \\
\hline 1. Feeling of moral obligation & 1 & & & & & & & & 10,32 & 2,807 \\
\hline 2. Feeling of solidarity & $.517^{* *}(, 00)$ & 1 & & & & & & & 10,31 & 2,787 \\
\hline 3. Perceived effectiveness of resistance & $.158^{* *}(.00)$ & $.231^{* *}(.00)$ & 1 & & & & & & 13,79 & 4,287 \\
\hline 5. Identification with the nation & $.180^{* *}(.00)$ & $.137^{* *}(.00)$ & $.075(.05)$ & $.203^{* *}(.00)$ & 1 & & & & 19,66 & 5,555 \\
\hline 6. Non-violent resistance & $.221^{* *}(.00)$ & $.285^{* *}(.00)$ & $.199^{* *}(.00)$ & $.080^{*}(.04)$ & $.099^{*}(.01)$ & 1 & & & 15,26 & 4,126 \\
\hline 7. Violent resistance & $.075(.05)$ & $.010(.79)$ & $.164^{* *}(.00)$ & $-.024(.53)$ & $-.050(.20)$ & $.132^{* *}(.00)$ & 1 & & 11,21 & 4,319 \\
\hline $\begin{array}{l}\text { 8. Resistance to outgroup's } \\
\text { victimization }\end{array}$ & $.195^{* *}(.00)$ & $.192^{* *}(.00)$ & $.241^{* *}(.00)$ & $.036(.36)$ & $.031(.43)$ & $.739^{* *}(.00)$ & $.765^{* *}(.00)$ & 1 & 26,47 & 6,354 \\
\hline
\end{tabular}

Note: $\mathrm{r}(\mathrm{p}) ;{ }^{*}$. The correlation is significant at the 0.05 level (two-tailed); **. The correlation is significant at the 0.01 level (two-tailed).

The results of Table 4 show that the feeling of moral obligation is present among the participants $(\mathrm{M}=10,32 ; \mathrm{SD}=$ $2,80)$. The same general trend is observed for the feeling of solidarity $(\mathrm{M}=10,31 ; \mathrm{SD}=2,87)$. Likewise, participants agree with the perceived effectiveness of resistance $(\mathrm{M}=13,79 ; \mathrm{SD}=$ 4,28). The data collected also reveals a high adherence to the perceived entitativeness of the supra-ordered group $(\mathrm{M}=13,52$; $\mathrm{SD}=4,59)$. This trend is also observed for the variable relating to national identification ( $\mathrm{M}=19,66 ; \mathrm{SD}=5,55)$. Regarding the correlational analyzes, this table shows that there is a positive and significant link between the feeling of moral obligation and the resistance to outgroup's victimization $(\mathrm{r}=.19 ; p<.01)$. This positive and significant link is also observed between the feeling of solidarity and resistance to outgroup's victimization $(r=.19$; $p<.01$ ). The same is true between the perceived effectiveness of resistance and resistance to outgroup's victimization $(r=.24$; $p<.01$ ). For perceived entitativeness of the supra-ordered group and resistance to outgroup's victimization, we also note a positive relationship $(\mathrm{r}=.036 ; p>.05)$. The same trends are observed for the variables relating to nation identification and resistance to outgroup's victimization $(\mathrm{r}=.031 ; p>.05)$.

Table 5. Regression analysis between control variables relating to personal dispositions and overall support for resistance to outgroup's victimization.

\begin{tabular}{|c|c|c|c|c|c|c|}
\hline \multirow{2}{*}{ Model } & \multicolumn{2}{|c|}{ Unstandardized coefficients } & \multirow{2}{*}{$\mathbf{T}$} & \multirow{2}{*}{ Sig. } & \multicolumn{2}{|c|}{$95.0 \%$ confidence interval for $B$} \\
\hline & B & Standard error & & & Lower bound & Upper bound \\
\hline 1. Feeling of moral obligation & .441 & .087 & 5,083 & .000 & .270 & .611 \\
\hline 2. Feeling of solidarity & .438 & .087 & 5,009 & .000 & .266 & 609 \\
\hline 3. Perceived effectiveness of resistance & .357 & .056 & 6,352 & .000 & .246 & .467 \\
\hline 4. Perceived entitativeness of the supra-ordered group & .049 & .054 & .911 & .363 & -.057 & .155 \\
\hline 5. Identification with the nation & .035 & .045 & .782 & .434 & -.053 & .123 \\
\hline
\end{tabular}

Note: Dependent variable: Overall support for resistance to outgroup's victimization.

The regression matrix above reveals that the strength of the effect of the feeling of moral obligation on overall support for resistance to outgroup's victimization is positive and significant $(\beta=.44 ; \mathrm{t}=5.08 ; p<.01 ; \mathrm{Ci}[.27 ; .61])$. This tendency is also perceived between the feeling of solidarity and the overall support for resistance to outgroup's victimization $(\beta=.43 ; \mathrm{t}=5 ; p<.01 ; \mathrm{Ci}[.26 ; .60])$, and between the perceived effectiveness of the resistance and the overall 
support for resistance to outgroup's victimization $(\beta=.35 ; \mathrm{t}=$ $6,35 ; p<.01 ; \operatorname{Ci}[.24 ; .46])$. We note a positive but not significant effect between perceived entitativeness of the supra-ordered group and overall support for resistance to victimization of the outgroup $(\beta=.049 ; \mathrm{t}=9,11 ; p>.05 ; \mathrm{Ci}[-$ $.057 ; .15])$. The same effect is observed between identification with the nation and the overall support of resistance to outgroup's victimization $(\beta=.035 ; \mathrm{t}=.78$; $p>.05 ; \mathrm{Ci}[-.053 ; .12])$. The regression analyzes of Table 6 confirm the correlation analyzes presented above.

\subsubsection{Statistical Analyzes Relating to Control Variables Specific to Ideological Dispositions}

This sub-section relates to the presentation of descriptive and inferential analyzes specific to the participants' ideological dispositions.

Table 6. Descriptive and correlation statistics between the control variables relating to ideological dispositions and the overall support for resistance to outgroup's victimization.

\begin{tabular}{|c|c|c|c|c|c|c|c|c|c|c|c|c|}
\hline & 1 & 2 & 3 & 4 & 5 & 6 & 7 & 8 & 9 & 10 & $\bar{M}$ & É.-T. \\
\hline 1. & 1 & & & & & & & & & & 10,09 & 4,844 \\
\hline 2. & $.411^{* *}(.00)$ & 1 & & & & & & & & & 11,80 & 5,600 \\
\hline 3. & $.309^{* *}(.00)$ & $.502^{* *}(.00)$ & 1 & & & & & & & & 14,19 & 5,467 \\
\hline 4. & $-.167^{* *}(.00)$ & $-.252^{* *}(.00)$ & $-.063(.10)$ & 1 & & & & & & & 16,01 & 4,226 \\
\hline 5. & $.238^{* *}(.00)$ & $.379^{* *}(.00)$ & $.252^{* *}(.00)$ & $-.284^{* *}(.00)$ & 1 & & & & & & 11,23 & 4,429 \\
\hline 6. & $.214^{* *}(.00)$ & $.406^{* *}(.00)$ & $.251^{* *}(.00)$ & $-.193^{* *}(.00)$ & $.323^{* *}(.00)$ & 1 & & & & & 24,57 & 7,179 \\
\hline 7. & $.005(.89)$ & $-.086^{*}(.02)$ & $.016(.67)$ & $.251^{* *}(.00)$ & $-.055(.16)$ & $-.020(.60)$ & 1 & & & & 15,10 & 5,731 \\
\hline 8. & $.258^{* *}(.00)$ & $.391^{* *}(.00)$ & $.324^{* *}(.00)$ & $-.117^{* *}(.00)$ & $.266^{* *}(.00)$ & $.336^{* *}(.00)$ & $.107^{* *}(.00)$ & 1 & & & 9,52 & 4,275 \\
\hline 9. & $-.130^{* *}(.00)$ & $-.225^{* *}(.00)$ & $-.091^{*}(.00)$ & $.348^{* *}(.00)$ & $-.237^{* *}(.00)$ & $-.154^{* *}(.00)$ & $.184^{* *}(.00)$ & $-.10^{* *}(.00)$ & 1 & & 16,26 & 3,838 \\
\hline 10. & $-.102^{* *}(.00)$ & $-.219^{* *}(.00)$ & $-.160^{* *}(.00)$ & $.250^{* *}(.00)$ & $-.070(.07)$ & $-.073(.06)$ & $.116^{* *}(.00)$ & $-.064(.10)$ & $.302^{* *}(.00)$ & 1 & 18,67 & 4,740 \\
\hline 11. & $-.010(.74)$ & $-.071(.07)$ & $-.015(.70)$ & $.031(.42)$ & $.006(.87)$ & $.049(.20)$ & $-.041(.29)$ & $.012(.75)$ & $.099^{*}(.01)$ & $.171^{* *}(.00)$ & 26,47 & 6,354 \\
\hline
\end{tabular}

Note: $\mathrm{r}(\mathrm{p}) ; *$. The correlation is significant at the 0.05 level (two-tailed); **. The correlation is significant at the 0.01 level (two-tailed).

$1=$ Belief in a just world; $2=$ Social system justification; $3=$ Linguistic system justification; $4=$ Belief in meritocracy; $5=$ Social dominance Orientation; $6=$ Linguistic dominance orientation; $7=$ Right-wing authoritarianism; $8=$ Blind patriotism; $9=$ Constructive patriotism; $10=$ Adherence to conspiracy theories; $11=$ Resistance to outgroup's victimization.

The results of Table 6 show that the participants adhere to the belief in a just world $(\mathrm{M}=10,09 ; \mathrm{SD}=4,84)$ and they do not justify the social $(M=11,80 ; S D=5,60)$ nor the linguistic systems $(M=14,19 ; \mathrm{SD}=5,46)$. They also have an inclination for meritocracy $(M=16,01 ; S D=4,22)$, linguistic dominance $(\mathrm{M}=24,57 ; \mathrm{SD}=7,17)$, and right-wing authoritarianism $(\mathrm{M}=$ $15,10 ; \mathrm{SD}=5,73)$, but not for social dominance $(\mathrm{M}=11,23$; $\mathrm{SD}=4,42)$. They adhere to constructive patriotism $(\mathrm{M}=16,26$; $\mathrm{SD}=3,83)$ but not to blind patriotism $(\mathrm{M}=9,52 ; \mathrm{SD}=4,27)$, nor to conspiracy theories $(M=18,64 ; \mathrm{SD}=4,74)$. Regarding correlational analyzes, this table reveals the existence of a negative and insignificant link between belief in a just world and resistance to outgroup's victimization $(\mathrm{r}=-.010 ; p>.05)$. This type of link is also observed between social system justification and resistance to outgroup's victimization $(\mathrm{r}=$ $.071 ; p>.05$, , as well as between linguistic system justification and resistance to outgroup's victimization $(r=$ -
$.015 ; p>.05)$. For the variables relating to belief in meritocracy and resistance to outgroup's victimization, we note a positive but not significant relationship $(\mathrm{r}=.031 ; p>.05)$. The same is true for the links between social dominance orientation and resistance to outgroup's victimization $(\mathrm{r}=.006 ; p>.05)$; linguistic dominance orientation and resistance to outgroup's victimization $(\mathrm{r}=.049 ; p>.05)$. The data also show that there is a negative and insignificant link between right-wing authoritarianism and resistance to outgroup's victimization ( $\mathrm{r}=$ $-.041 ; p>.05)$ and a positive and insignificant link between blind patriotism and resistance to outgroup's victimization $(\mathrm{r}=.012 ; p>.05)$. This tendency is much more observed between constructive patriotism and resistance to outgroup's victimization $(\mathrm{r}=.099 ; p>.05)$ and between adherence to conspiracy theses and resistance to outgroup's victimization $(\mathrm{r}=.17 ; p>.01)$, with a positive and significant link.

Table 7. Regression analysis between the control variables relating to the ideological dispositions of the participants and the overall support for the resistance to outgroup's victimization.

\begin{tabular}{|c|c|c|c|c|c|c|}
\hline \multirow{2}{*}{ Model } & \multicolumn{2}{|c|}{ Unstandardized coefficients } & \multirow{2}{*}{$\mathbf{T}$} & \multirow{2}{*}{ Sig. } & \multicolumn{2}{|c|}{$95.0 \%$ confidence interval for $B$} \\
\hline & B & Standard error & & & Lower bound & Upper bound \\
\hline 1. Belief in a just world & -.013 & .051 & -.61 & .794 & -.114 & .087 \\
\hline 2. Social system justification & -.080 & .044 & $-1,813$ & .070 & -.167 & .007 \\
\hline 4. Belief in meritocracy & .047 & .059 & .806 & .421 & -.068 & .163 \\
\hline 5. Social dominance orientation & .009 & .056 & .160 & .873 & -.101 & .119 \\
\hline 6. Linguistic dominance orientation & .043 & .035 & 1,260 & .208 & -.024 & .111 \\
\hline 8. Blind patriotism & .018 & .058 & .309 & .757 & -.096 & .132 \\
\hline 9. Constructive patriotism & .165 & .064 & 2,560 & .011 & .038 & .291 \\
\hline 10. Adherence to conspiracy theories & .229 & .052 & 4,438 & .000 & .128 & .330 \\
\hline
\end{tabular}

Note: Dependent variable: Overall support for resistance to outgroup's victimization. 
The regression matrix above reveals that the trend in the strength of the effect of belief in a just world on overall support for resistance to outgroup's victimization is negative and insignificant $(\beta=-.013 ; \mathrm{t}=-.26 ; p>.05 ; \mathrm{Ci}[-.11 ; .087])$. It is the same between social system justification and the overall support for resistance to the victimization of the outgroup ( $\beta=-.080 ; \mathrm{t}=-1,81 ; p>.05 ; \mathrm{Ci}[-16 ; .007])$, as well as between linguistic system justification and the overall support for resistance to outgroup's victimization ( $\beta=-.017$; $\mathrm{t}=-.37 ; p>.05 ; \mathrm{Ci}[-10 ; .072])$. Meritocracy has a positive but insignificant effect on overall support for resistance to outgroup's victimization $(\beta=.047 ; \mathrm{t}=.80 ; p>.05 ; \mathrm{Ci}[-$ $.068 ; .16])$, just like social dominance orientation $(\beta=.009$; $\mathrm{t}=.16 ; p>.05 ; \mathrm{Ci}[-.101 ; .11])$ and linguistic dominance orientation $(\beta=.043 ; \mathrm{t}=.1,26 ; p>.05 ; \mathrm{Ci}[-.024 ; .11])$. The data collected also show that the strength of the effect of rightwing authoritarianism on overall support for resistance to outgroup's victimization is negative and not significant ( $\beta=$ $.045 ; \mathrm{t}=-1,04 ; p>.05 ; \mathrm{Ci}[-.13 ; .040])$. On the other hand, it is positive and not significant for blind patriotism $(\beta=.018$; $\mathrm{t}=.30 ; p>.05 ; \mathrm{Ci}[-.096 ; .13])$ and positive and significant for constructive patriotism $(\beta=.16 ; \quad \mathrm{t}=2,56 ; \quad p>.05$; $\mathrm{Ci}[.038 ; .29])$. This trend is also observed for adherence to conspiracy theories $(\beta=.22 ; \mathrm{t}=4,43 ; p<.01 ; \mathrm{Ci}[.12 ; .33])$. In conclusion, these analyzes reveal that the support for resistance towards outgroup's victimization can only be accentuated when the participants do not adhere to the ideologies that legitimize social inequalities, and when they are in agreement with personal dispositions.

\section{Discussion}

The present study, conducted in the Cameroonian linguistic context, tested the hypothesis that intergroup emotions have a moderating effect on the link between selfperception as an inclusive victim of oppression and support for resistance to the victimization of a disadvantaged outgroup. Specifically, it was expected that: self-perception as an inclusive victim of outgroup's oppression generates various intergroup emotions (nostalgia for others, empathy for others, collective guilt, collective shame and collective grievances) that will elicit support from participants in the resistance to outgroup's victimization. The data collected provides empirical support for these predictions, hence the conclusion that intergroup emotions generated by selfperception as an inclusive victim of oppression impact on participants' inclination to resist to the victimization of Anglophones in Cameroon.

The specialized literature indicates that individuals are likely to engage in collective action when they experience a high feeling of nostalgia. Indeed, if in its negative aspect it is likely to push them to adopt hostile attitudes towards outgroup [13], it remains that in its positive aspect, it can generate the reduction of intergroup prejudices. Indeed, this individual disposition is reduced by the feeling of nostalgia insofar as it promotes engagement in desirable, lasting and memorable interactions with others. This feeling also promotes charitable behavior towards others, not least because it tends to increase the activation of empathy in people; which predisposes them to help people in need by investing in charitable works for example [1]. The specialized literature clearly indicates that empathy is positively linked to prosocial behaviors, in particular because it inhibits aggression and antisocial behaviors [70]. Consistent with this data from the literature, the results of this research reveal that participants who feel empathy towards Anglophones have a high propensity to support resistance against their oppression by the gorverning system.

Just as much as nostalgia for others and empathy, collective guilt generated by self-perception as an inclusive victim of oppression is at the origin of the support of the resistance to outgroup's victimization among the participants of this study. The literature on this question reveals that there are links between collective guilt and populations' support for redressing intergroup tensions [30, 38]. In this vein, a study carried out in the Cameroonian context reports that the collective guilt felt by Francophones motivates them to support the reparation of oppression towards the anglophone outgroup [45]. This emotion stems from the perception that ingroup is the perpetrator of unjust action, crossing moral boundaries. It also reflects negative emotional states that put individuals in a situation of discomfort, hence their desire to repair the harm caused, in particular by working in favor of the reconciliation process and by supporting reparation policies or public apologies [18]. This trend could be motivated by the awareness that members of the victimized outgroup are suffering because ingroup acts. Concretely, this means that the participants of this study feel the desire to restore their group image threatened by the discriminatory and repressive behavior of the elites of their linguistic community against the anglophone minority.

The results of the present study confirm that collective shame is linked to various prosocial behaviors that can manifest as support for resistance against the oppression of a disadvantaged outgroup. Shame, when experienced, encourages positive behavior, including compliance and responsibility. More specifically, motivated by feelings of shame, individuals are more inclined to restore a positive identity or to take compensatory actions to repair damaged intergroup relationships. This is because shame is likely to be felt when they think that a transgression tarnishes the image and identity of the group [29]. In this vein, the literature indicates that collective shame can promote prosocial behaviors that serve to repair the identity of the group, in particular by respecting norms, adopting prosocial behaviors and condemning anti-social behaviors [1].

The grievances felt by the participants of this study motivate them to support the resistance against Anglophones' oppression. The literature on this subject mentions that grievances arise from the relative deprivation experienced by individuals. Groups feel relatively deprived when making negative comparisons with people or groups that are similar 
to them [24]. This feeling is the consequence of the gap that exists between what is and what should be [25]. As a result, studies of protest show that people participate to voice their grievances about relative deprivation, frustration or perceived injustice $[9,25,41]$. These grievances arise when individuals feel relatively deprived for themselves, for their group or for others, due to being faced with living conditions they did not expect [8]. Thus, at the heart of any protest are grievances which are the experience of illegitimate inequalities and injustices. In other words, individuals express their dissatisfaction or at least engage in collective actions when they experience situations of inequality, as it is the case in the Cameroonian context.

\section{Conclusion}

The objective of this study was to fill the gaps in the literature on resistance to victimization, in particular by analyzing the effect of self-perception as an inclusive victim of oppression on the tendency to support resistance to outgroup's victimization. Self-perception as an inclusive victim of oppression was conceived as a catalyst for intergroup emotions directly responsible for the resistance to outgroup's victimization. The data collected in the Cameroonian context provide empirical support for this thesis. More specifically, nostalgia for others, empathy for others, collective guilt, collective shame and collective grievances lead individuals to adopt prosocial behaviors in general, and support for resistance to victimization in particular, in favor of disadvantaged groups.

\section{References}

[1] Abeyta, A. A., Routledge, C., \& Juhl, J. (2015). Looking back to move forward: Nostalgia as a psychological resource for promoting relationship goals and overcoming relationship challenges. Journal of Personality and Social Psychology, 109 (6), 1029-1044. https://doi.org/10.1037/pspi0000036

[2] Allpress, A. J., Barlow, F. K., Brown, R., \& Louis, W. R. (2010). Atoning for Colonial Injustices: Group-Based Shame and Guilt Motivate Support for Reparation. International Journal of Conflict and Violence, 4 (1), 75-88.

[3] Altemeyer, B. (1998). The other "authoritarian personality". Advance in Experimental Social Psychology, 30, 47-92. https://doi.org/10.1016/S0065-2601(08)60382-2.

[4] Andrighetto, L., Mari, S, Volpato, C., \& Behluli, B. (2012). Reducing competitive victimhood in Kosovo: The rle of extended contact and common ingroup identity. Political Psychology, 33, 513-529. doi: 10.1111/j.14679221.2012.00887.x.

[5] Asal, V., Legault, R., Szekely, O., \& Wilkenfeld, J. (2013). Gender ideologies and forms of contentious mobilization in the Middle East. Journal of Peace Research, 50, 305-318. doi: https://doi.org/10.1177/0022343313476528.

[6] Ayanian, A. H., Tausch, N., Acar, Y. G., Chayinska, M., Cheung, W-Y., \& Lukyanova, Y. (2021). Resistance in repressive contexts: A comprehension test of psychological predictors. Jounal of Personality and Social Psychology, 120 (4), 912-939. doi: 10.1037/pspi0000285.

[7] Barakat, Z. \& Fakih, A. (2021). Determinants of the Arab Spring Protests in Tunisia, Egypt, and Libya: What Have We Learned? Social Sciences, $10 \quad$ (282). https://doi.org/10.3390/socsci10080282.

[8] Becker, G., \& Tausch, N. (2015). A dynamic model of engagement in normative and non-normative collective action: psychological antecedents, consequences, and barriers. European Review of Social Psychology, 26 (1), 43-92. https://doi.org/10.1080/10463283.2015.1094265.

[9] Berkowitz, L. (1972). Frustration, comparisons, and other sources of emotion arousal as contributors to social unrest. Journal of Social Issues, 28, 77-91. https://doi.org/10.1111/j.1540-4560.1972.tb00005.x.

[10] Blackwood, L., Livingstone, A. G., \& Leach, C. W. (2013). Regarding societal change. Journal of Social and Political Psychology, 1, 105-111. doi: 10.5964/jspp.vli1.282.

[11] Brewer, M. B. (1991). The social self-on being same and different at the same time. Personality and Social Psychology Bulletin, 17, 475-482. https://doi.org/10.1177\%2F0146167291175001.

[12] Brotherton, R., French, C. C., \& Pickering, A. D. (2013). Measuring belief in conspiray theories: The Generic Conspiracist Beliefs Scale. Frontiers in Psychology, 4, 279287. http://dx.doi.org/10.3389/fpsyg.2013.00279.

[13] Cheung, W. Y., Sedikides, C., \& Wildschut, T. (2017). Nostalgia proneness and reduced prejudice. Personality and Individual Differences, 109, 89-97. https://doi.org/10.1016/j.paid.2016.12.045.

[14] Christie, D. J., Tint, B., Wagner, R. V., \& Winter, D. D. (2008). Peace psychology for a peaceful world. American Psychologist, 63 (6), 540-52. doi: 10.1037/0003-066X.63.6.540.

[15] Chueng, W-Y., Sedikides, C., Tausch., N. \& Ayanian, A. H. (2017). Collective nostalgia is associated with stronger outgroup-directed anger and participation in ingroup-favoring collective. Journal of Social and Political Psychology, 5 (2), 301-319. https://doi.org/10.5964/jspp.v5i2.697.

[16] Crisp, R. J., Stone, C. H., \& Hali, N. R. (2006). Recategorization and subgroup identification: Predicting and preventing threats from common ingroups. Personality and Social Psychology Bulletin, 32 (2), 230-243. doi: 10.1177/0146167205280908.

[17] Devos, T. (2005). Identité sociale et émotions intergroupes. Les Cahiers Internationaux de Psychologie Sociale, 67 (68), 85-100.

[18] Doosje, B., Brabscombe, N. R., Spears, R., \& Manstead, A. S. R. (1998). Guilty by association: When one's group has a negative history. Journal of Personality and Social $\begin{array}{llll}\text { Psychology, } & 75 & \text { (4), }\end{array}$ https://psycnet.apa.org/doi/10.1037/0022-3514.75.4.872.

[19] Einwohmer, R. L. (2003). Opportunity, honor and action in the Warsaw Ghetto Uprising of 1943. American Journal of Sociology, 109, 650-675. doi: 10.1086/379528.

[20] Einwohmer, R. L. (2009). The need to know: Cultured ignorance and Jewish resistance in the ghetto of Warsaw, Vilna and Lodz. Sociological Quarterly, 50, 407-430. doi: 10.1111/j.1533-8525.2009.01146.x. 
[21] Ekango Nzekaih, H. K. (2018). Effet de l'appartenance catégorielle sur la justification du système linguistique au Cameroun: la passivité à l'égard de la dévaluation culturelle comme facteur facilitateur de la justification du système [Unpublished Master's Thesis]. University of Dschang.

[22] Fonchingong, T. (2013). The quest for autonomy: The case of Anglophone Cameroon. African Journal of Political Science and International Relations, 7 (5), 224-236. http://dx.doi.org/10.5897/AJPSIR10.033.

[23] Galtung, J. (1969). Violence, peace, and peace research. Journal of Peace Research, 6 (3), 167-191. http://www.jstor.org/stable/422690.

[24] Guimond, S., \& Tougas, F. (1994). Sentiment d'injustice et action collective: La théorie de la privation relative. In R. Bourhis \& J.-P. Leyens (Éds.), Stéréotypes, discrimination et relations intergroupes, 201-231.

[25] Gurr, T. R. (1970). Why men rebel. PUP.

[26] Haslam, S. A., \& Reicher, S. D. (2012). When prisoners take over the prison: A social psychology of resistance. Personality and Social Psychology Review, 16 (2), 154-179. doi: 10.1177/1088868311419864.

[27] Hollander, J. A., \& Einwohner, R. L. (2004). Conceptualizing resistance. Sociological Forum, 19 (4), 533-554. doi: 10.1007/s11206-004-0694-5.

[28] Iyer, A., \& Leach, C. W. (2008). Emotion in intergroup relations. European Review of Social Psychology, 19 (1), 86125. https://doi.org/10.1080/10463280802079738.

[29] Iyer, A., Leach, C. W., \& Crosby, F. J. (2003). White guilt and racial compensation: The benefits and limits of self-focus. Personality and Social Psychology Bulletin, 29 (1), 17-29. doi: 10.1177/0146167202238377.

[30] Iyer, A., Schamader, T., \& Lickel, B. (2007). Why individual protest the perceived transgressions of their country: The role of anger, shame and guilt. Personality and Social Psychology Bulletin, 33 (4), 572-87. doi: 10.1177/0146167206297402.

[31] Jasini, A., Delvaux, H., \& Mesquita, B. (2017). Collective victimhood and ingroup identity jointly shape intergroup relations, even in a Non-violent conflict: The case of the Belgians. Psychologica Belgica, 57 (3), 98-114. doi: http://doi.org/10.5334/pb.334.

[32] Jost, J. T., Banaji, M. R., \& Nosek, B. A. (2004). A decade of system justification theory: accumulated evidence of conscious of the statu quo. Political Psychology, 25 (6), 881920. https://doi.org/10.1111/j.1467-9221.2004.00402.x.

[33] Kay, A. C., \& Jost, J. T (2003). System justification scale. APA Psyc Tests. https://doi.org/10.1037/t22834-000.

[34] Kelly, C. (2011). Group identification collective action. European Review of Social Psychology, 4 (1), 59-83. doi.org/10.1080/14792779343000022.

[35] Klar, Y., Schori-Eyal, N., \& Klar, Y. (2013). The "Never Again" state of Israel: The emergence of the Holocaust as a core feature of Israeli identity and its four incongruent voices. Journal of Social Issue, 69 (1), 125-143. doi: 10.111josi.12007.

[36] Kurer, T., Häusermann, S., Wüest, B., \& Enggist, M. (2019). Economic Grievances and Political Protest. European Journal $\begin{array}{lllll}\text { of Political Research, } 58 \quad \text { (3), 866-892. } & \text { 8) }\end{array}$ https://doi.org/10.1111/1475-6765.12318.

[37] Landau, Y. (2003). Healing the holy land: Interreligious peacebuilding in Israel/Palestine. United States Institute of Peace, 51. https://lccn.loc.gov/2003373618.

[38] Leach, C. W., Iyer, A., \& Pederson, A. A. (2006). Anger and guilt about ingroup advantage explain the willingness for political action. Personality and Social Psychology Bulletin, $32 \quad$ (9), 32-45. https://doi.org/10.1177\%2F0146167206289729.

[39] LeFebvre, R. K., \& Armstrong, C. (2018). Grievance-based social movement mobilization in the \#Ferguson Twitter storm. New Media \& Society, 20 (1), 8-28. doi: $10.1177 / 1461444816644697$.

[40] Licata, L. \& Klein, O. (2010). Holocaust or benevolent paternalism? Intergenerational comparisons on collective memories and emotions about Belgium's colonial past. International Journal of Conflict and Violence, 4 (1), 45-57. https://doi.org/10.4119/ijcv-2814.

[41] Lind, E. A., \& Tyler, T. R. (1988). The social psychology of procedural justice. Springer Science \& Business Media. 10.1007/978-1-4899-2115-4.

[42] McCoy, K. S., Cosley, B., Saslow, L., \& Epel, E. (2013). Is the belief in merotocratcy palliative for members of low status groups? Evidence for a benefit for self-esteem and physical health via perceived control. European Journal of Social Psychology, 43 (4), 307-318. doi: 10.1002/ejsp.1959.

[43] Messanga, G. A. \& Ekango Nzekaih H. K. (2021). Political instrumentalization of ethnicity and maintenance of social status quo in multi-ethnic contexts. International Journal of Applied Psychology, 11 (2), 43-52. doi: 10.5923/j.ijap.20211102.01.

[44] Messanga, G. A., \& Nzeuta Lontio, S. (in press). Évaluation psychométrique de l'entitativisation dans les relations intergroupes Anglophones/Francophones au Cameroun. À

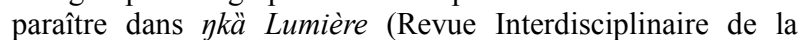
Faculté des Lettres et Sciences Humaines de l'Université de Dschang).

[45] Messanga, G. A., Ekango Nzekaih, K. H., \& Npiane Ngongeu, S. (2020). Effet de la Culpabilité Groupale Ressentie sur le Soutien à la Réparation de L'oppression à l'égard de l'exogroupe: Le cas des Anglophones du Cameroun. European Scientific Journal, 16 (10), 135-153. doi: 10.19044/esj.2020.v16n10p135.

[46] Messanga, G. A., Fotso Magne, P., \& Taffo Nemboue, W. (2020). Adhésion aux théories conspirationnistes et soutien aux politiques répressives à l'égard des libertés politiques en contexte de démocratie autoritaire: Le Cas du Cameroun. European Scientific Journal, 16 (26), 51-73. doi: http://dx.doi.org/10.19044/esj.2020.v16n26p51.

[47] Mosley, D. V., Neville, H. A., Chavez-Dueñas, N. Y., Adames, H. Y., Lewis, J. A., \& French, B. H. (2020). Radical hope in revolting times: Proposing a culturally relevant psychological framework. Social and Personality Psychology Compass, 14 (1), 1-12. doi: 10.1111/spc3.12512.

[48] Muliavka, V. (2020) Bringing grievances back into social movement research: the conceptual and empirical case. Social Movement Studies. doi: 10.1080/14742837.2020.1858042. 
[49] Nadler, A., \& Shnabel, N. (2015). Intergroup reconciliation: Instrumental and socio-emotional processes and the needsbased model. European Review of Social Psychology, 26 (1), 93-125. doi: 10.1080/10463283.2015.1106712.

[50] Noor, M., Vollhardt, J. R., Mari, S., \& Nadler, A. (2017). The social psychology of collective victimhood. European Journal of Social Psychology, 47 (2), 121-134. https: //doi.org/10.1002/ejsp.2300.

[51] Ntap, E. J. (2018). Affrontements entre séparatistes anglophones et l'armée à Buea au Cameroun. www.voaafrique.com

[52] Okado, L. T. A., \& Ribeiro, E. A. (2020). Individual Conditioning Factors of Political Protest in Latin America: Effects of Values, Grievance and Resources. Brazilian Political Science Review, 14 (3). https://doi.org/10.1590/19813821202000030002.

[53] Parant, A. (2014). Préserver la distinctivité pour améliorer les relations intergroupes par la recatégorisation: D'un Common Ingroup à un Common Outgroup. Thèse de doctorat en psychologie publié, Université de Bordeaux. https://tel.archives-ouvertes.fr/tel-01176851.

[54] Pratto, F. (2019). Power dynamics in intergroup relations. Current Opinion in Psychology, 33, 250-255. doi: 10.1016/j.copsyc.2019.10.00.

[55] Pratto, F., Sidanius, J, Stallworth, L., \& Malle, B. (1994). Social dominance orientation: A personality variable predicting social and political attitude. Journal of Personality and social Psychology, $67 \quad$ (4), 741-763. https://doi.org/10.1037/0022-3514.67.4.741.

[56] Prilletensky, I. (2008). The role of power in wellness, oppression, and liberation: the promise of psychopolitical validity. Journal of Community Psychology, 36 (2), 116-136. doi: $10.1002 /$ jcop. 20225.

[57] Razafindrakoto, M., \& Roubaud, F. (2018). Sous la crise Anglophone au Cameroun: frustration politique et défiance à l'égard des autorités publiques. https://www.documentation.ird.fr/hor/fdi:010074743.

[58] Saab, R., Spears, R., Tausch, N., \& Sasse, J. (2016). Predicting aggressive collective action based on the efficacy of peaceful and aggressive actions. European Journal of Social Psychology, 46 (5), 529-543. doi: 10.1002/ejsp.2193.

[59] Schatz, R. T., Staub, E., \& Lavine, H. (1999). On the varieties of national attachment: blind versus constructive patriotism. Political Psychology, $20 \quad$ (1), 151-174. https://doi.org/10.1111/0162-895X.00140.

[60] Sibley, G. C., \& Wilson, M. S. (2007). Political attitudes and the ideology of equality: Differentiating support for liberal and conservative political parties in New Zealand. New Zelaland Journal of Psychology, 36 (2), 72-84.

[61] Smith, E. R., Seger, C. R., \& Mackie, D. M. (2007). Can emotions be truly group level? Evidence regarding four conceptual criteria. Journal of Personality and Social Psychology, 93 (3), 431-446. doi: 10.1037/0022-3514.93.3.431.

[62] Soudan, C., \& Gangloff. (2012). La croyance au monde juste comme facteur explicatif de diverses réactions à des injustices professionnelles. Psychologie du Travail et des Organisations, 18 (4), 171-185. http://dx.doi.org/10.1016/S14202530(16)30077-2.
[63] Sourna Loumtouang, E. (2016). Chômage des jeunes et stabilité sociopolitique au Cameroun de 1990 à nos jours. Council for the Development of Social Science in Africa (CODESRIA), Doi: 10.13140/RG.2.1.4885.5449.

[64] Staub, E. (2012). Psychology and morality in genocide and violent conflict: Perpetrators, passive bystanders, and rescuers. In M. Mikulincer \& P. R. Shaver (Eds.), The Social Psychology of Morality: Exploring the causes of good and evil (pp. 381-398). American Psychological Association. https://doi.org/10.1037/13091-021.

[65] Staub, E. (2013). Building a peaceful society: Origins, prevention, and reconciliation after genocide and other group violence. American Psychology, 68 (7), 576-589. https://doi.org/10.1037/a0032045.

[66] Suedfeld, P. (1999). Toward a taxonomy of ethnopolitical violence: Is collective killing by any other name still the same? Peace and Conflict. Journal of Peace Psychology, 5 (4), 349-355. https://doi.org/10.1207/s15327949pac0504_5.

[67] Tausch, N., Becker, J. B., Spars, R., \& Christ, O. (2011). Explaining radical group behavior: developing emotion and efficacy routes to normative and non normative collective action. Journal of Personality and social Psychology, 101 (1), 129-148. Doi: 10.1037/a0022728.

[68] Tchinda Kenfo, J. (2017). Le problème anglophone" au Cameroun: la réponse par le processus participatif au développement territorial. www.thinkingafrica.org.

[69] Tec, N. (2013). Resistance: Jews and Christians Who Defied the Nazi Terror. Oxford University Press.

[70] Telle, N.-T., \& Pfister, H.-R. (2016). Positive Empathy and Prosocial Behavior: A Neglected Link. Emotion Review, 8 (2), 154-163. https://doi.org/10.1177/1754073915586817

[71] Thomas, E. F., McGarty, C., \& Mavor, K. I. (2009). Transforming "apathy into movement": The role of prosocial emotions in motivating action for social change. Personality and Social Psychology Review, 13 (4), 10-33. doi: 10.1177/1088868309343290.

[72] Tiedens, L. Z., \& Leach, C. W. (2004). The social life of emotions. Cambridge University Press.

[73] Tsapi Fomena, S. (2018). Construction et validation d'une échelle psychométrique de dominance linguistique [Unpublished Master's Thesis]. University of Dschang.

[74] Vargas-Salfate, S. \& Miranda, R. (2020). Nationalism, Patriotism, and Legitimation of the National Social Systems. Revista de Psicología, 38, 423-450. 10.18800/psico.202002.003.

[75] Vollhardt, J. R. (2012). Collective victimisation. In L. Tropp (Ed.), The Oxford handbook of intergroup conflict (pp. 136157). doi: 10.1093/oxfordhb/9780199747672.013.000.

[76] Vollhardt, J. R. (2013). "Crime against humanity" or "crime against Jews"? Acknowledgment in construals of the Holocaust and its importance for intergroup relations. Journal of Social Issues, 69 (1), 144-161. doi: 10.1111/josi.12008.

[77] Vollhardt, J. R., \& Bilali, R. (2015). The role of inclusive and exclusive victim consciousness in predicting intergroup attitudes: Findings from Rwanda, Burundi and DRC. Political Psychology, 365 (5), 489-506. doi: 101111/pops.1274. 
[78] Vollhardt, J. R., \& Staub, E. (2011). Inclusive altruism born of suffering: The relationships between adversity and prosocial attitudes and behavior toward disadvantaged outgroups. American Journal of Orthopsychiatry, 81 (3), 307-15. doi: 10.1111/j.1939-0025.2011.01099.X.

[79] Vollhardt, J. R, Nair, R., \& Tropp, L. R. (2016). Inclusive victim consciousness predicts minority group members' support for refugees and immigrants. Journal of Applied Social Psychology, 46 (6), 354-368. doi: 10.111/jasp.12368.
[80] Vollhardt, J. R., Okuyan, M., \& Ünal, H. (2020). Resistance to collective victimization and oppression. Current Opinion in Psychology,

35 92-97. https://doi.org/10.1016/j.copsyc.2020.04.001.

[81] Zhou, X., Wildschut, T., Sedikides, C., Shi, K., \& Feng, C. (2012). Nostalgia: The Gift That Keeps on Giving. Journal of Consumer Research, 39, 39-50. 10.1086/662199. 